\title{
FY-05 First Quarter Report On Development Of A Supercritical Carbon Dioxide Brayton Cycle: Improving PBR Efficiency And Testing Material Compatibility
}

NERI Quarterly Progress Report

Chang Oh

Richard Moore

Thomas Lillo

William Windes

Terry Totemeier

January 2005

The INL is a U.S. Department of Energy National Laboratory operated by Battelle Energy Alliance

Idaho National Laboratory 


\title{
FY-05 First Quarter Report On Development Of A Supercritical Carbon Dioxide Brayton Cycle: Improving PBR Efficiency And Testing Material Compatibility
}

NERI Quarterly Progress Report

\author{
Chang Oh \\ Richard Moore \\ Thomas Lillo \\ William Windes \\ Terry Totemeier
}

January 2005

Idaho National Laboratory

Idaho Falls, Idaho 83415

Prepared for the

U.S. Department of Energy

Assistant Secretary for Nuclear Energy

Under DOE Idaho Operations Office

Contract DE-AC07-05ID14517 


\section{NERI QUARTERLY PROGRESS REPORT}

Project Title: Development of a Supercritical Carbon Dioxide Brayton Cycle: Improving PBR Efficiency and Testing Material Compatibility

Covering Period: October 1, 2004 through December 31, 2004

Date of Report: January 30, 2005

Recipient: Kenny Osborne, DOE-ID

Award Number: $\quad$ M2SF 02-0190

Project Number: $\quad 02-190$

Principal

Investigator: Dr. Chang Oh

208-526-7716, chh@inel.gov

Collaborators: $\quad$ Richard Moore; 208-526-9671; rmm@inel.gov

Thomas Lillo; 208-526-9746; tml@inel.gov

William Windes; 208-526-6985; wew@inel.gov

Terry Totemeier; 208-526-3074; totetc@inel.gov

Project Objective: The objective of this research is to improve a helium Brayton cycle and to develop a supercritical carbon dioxide Brayton cycle for the Pebble Bed Reactor (PBR) that can also be applied to the Fast Gas-Cooled Reactor (FGR) and the Very-High-Temperature GasCooled Reactor (VHTR). The proposed supercritical carbon dioxide Brayton cycle will be used to improve the PBR, FGR, and VHTR net plant efficiency. Another objective of this research is to test materials to be used in the power conversion side at supercritical carbon dioxide conditions. Generally, the optimized Brayton cycle and balance of plant (BOP) to be developed from this study can be applied to Generation-IV reactor concepts. Particularly, we are interested in VHTR because it has a good chance of being built in the near future.

Background: $\quad$ The VHTR configuration is very important along with the choice of the working fluid. We started investigating a number of various VHTR configuration particularly in the power conversion unit. This will be our main focus for the year 3 activities. In conjunction with this main focus, our study will include the combined cycle, cycle with multiple reheat option, the recompression cycle, and others. 
Highlights of the first quarter activities of FY-05 are summarized below:

- Cycle efficiencies as well as differential cycle efficiencies (efficiency improvement per stage) were examined as a function of the number of input and rejection stages for several cycles including recuperated helium Brayton cycle, recuperated supercritical $\mathrm{CO}_{2}$ Brayton with split flow cycle, and Implication of IH\&C to system layout.

- $\quad$ Completed Task 3-1 Characterization of creep deformation of MA 754

- Submitted publication highlighting the creep testing results of fine-grained MA 754 (3-1-3 Mechanical and creep properties of thermo-mechanically processed MA 754). The manuscript, entitled "Elevated Temperature Strength of FineGrained INCONEL Alloy MA754”, was submitted to Metallurgical Transactions, A.

- $\quad$ Acquired a new super-critical $\mathrm{CO}_{2}$ system for corrosion testing of materials. The system had previously been used for long term corrosion testing in supercritical $\mathrm{CO}_{2}$ at lower temperatures $\left(600-700^{\circ} \mathrm{C}\right.$ maximum). Minor modifications to the system will be required to use at the temperatures and pressures of interest to this work. The testing equipment consists of a pump, tube furnace and five separate tubes in which samples can be tested simultaneously.

Status:

Task 1. Development of $\mathrm{CO}_{2}$ Brayton Cycle

Tasks 1-1, 1-2, 1-3, 1-4, and 1-5 were completed in the second and the third quarter of FY-03.

Task 2. Improvement of HTGR Net Efficiency

The objective of this task is to improve the overall plant cycle efficiency by the combination of the increased efficiency of each component in the secondary side of the HTGR. To accomplish this task, we performed a number of HYSYS simulation to investigate interstage heating and cooling (IH\&C). IH\&C is an attractive option for improving the efficiency of the NGNP power conversion system. As additional stages are added, the average temperature over which input energy is added stays higher and/or the average temperature over which rejection energy is removed stays lower. If this were the only impact of the IH\&C, the cycle efficiency would always increase with more stages. But with each additional stage, pressure drop is present. Additional interstage pumping must be accomplished to make up for this additional pressure drop. Because the pumps are not $100 \%$ efficient, eventually the entropy loss during an additional pumping operation results in a smaller total energy input than without that stage. When this occurs, the cycle efficiency actually decreases.

Cycle efficiencies as well as differential cycle efficiencies (efficiency improvement per stage) were examined as a function of the number of input and rejection stages for several cycles including: 
- Recuperated Helium Brayton cycle

- Recuperated $80 \% \mathrm{~N}_{2} 20 \%$ He (by weight) Brayton cycle

- Recuperated Supercritical $\mathrm{CO}_{2}$ Brayton with split flow cycle

- Implication of gas or liquid intermediate loop

- Implication of IH\&C to system layout

Interstage heating is used to increase the inlet temperature of the turbines and increase turbine work. However, interstage heating with a gas cooled reactor has not been found to be practical due to large pressure loss incurred to perform reheating [Peterson, 2003]. To determine the effects interstage cooling on cycle efficiency 1, 2 and 3 intercoolers were added to the basic indirect recuperated Helium and $\mathrm{N}_{2} / \mathrm{He}$ mixture cycles. The pressure drop through the precooler was set at $20 \mathrm{kPa}$. With a 1-intercooler layout the intercooler pressure drop was set to $50 \mathrm{kPa}$. With 2 intercoolers the first intercooler pressure drop was set to $37 \mathrm{kPa}$ and the second intercooler set to a pressure drop of 50 $\mathrm{kPa}$. With a 3-intercooler layout the first, second and third intercooler pressure drops were set to 30,40 and $50 \mathrm{kPa}$, respectively. These pressure drops were chosen because they are representative of pressure drops used by a MIT studied on an indirect Helium Brayton cycle with a maximum system pressure of $8 \mathrm{MPa}$ [Wang, 2003].

A base design for each cycle was determined and input into HYSYS. HYSYS was then used to simulate and optimize each cycle.

\section{- Recuperated Helium Brayton cycle}

The base cycle used in for this study was the indirect Helium cycle and operating conditions used in this section are summarized in Table 2.2-1. The efficiency without intercooling was $45.19 \%$. The efficiency with 1, 2 and 3 intercoolers was $48.25 \%$, $48.92 \%$ and $49.07 \%$, respectively.

\section{- Recuperated $80 \% \mathrm{~N}_{2} 20 \%$ He (by weight) Brayton cycle}

The base cycle used in for this study was the indirect $\mathrm{N}_{2} / \mathrm{He}$ cycle and conditions used in this section are shown in Table 1. The efficiency without intercooling was $45.29 \%$. The efficiency with 1, 2 and 3 intercoolers was $49.39 \%, 50.19 \%$ and $50.47 \%$, respectively.

\section{- Recuperated Supercritical $\mathrm{CO}_{2}$ Brayton with split flow cycle}

The base design chosen for the supercritical $\mathrm{CO}_{2}$ was developed at MIT [Dostal et al., 2004]. Split flow is an option for improving cycle efficiency when the working fluid is operated near its critical point. Around the critical point the fluid properties vary greatly. To take advantage of this the flow is split and a portion goes to a precooler before entering the compression stage. By compressing around the critical point the compressor work can be significantly reduced.

The model developed at MIT was repeated in HYSYS to ensure consistency between the two models. The MIT model with a $600 \mathrm{MW}(\mathrm{t})$ reactor power and a $700{ }^{\circ} \mathrm{C}$ reactor outlet temperature was simulated in HYSYS. The MIT model gave a cycle efficiency of 
$51.3 \%$ and the HYSYS model gave an efficiency of $51.1 \%$. Since the models were comparable the base model was then modified in HYSYS. The MIT design was modified to be an indirect cycle with a reactor outlet temperature of $867^{\circ} \mathrm{C}$. Next the heat flow in the IHX was set to $600 \mathrm{MW}(\mathrm{t})$ to be consistent with the amount of power supplied to the PCS. The design parameters for the modified cycle are detailed in Table 2.

The HYSYS optimized recompression cycle produced a cycle efficiency of $52.09 \%$ compared to the $51.1 \%$ for the base model. Although this cycle has a slightly higher efficiency, it may not be advantageous from the point of additional capital costs and the potential material problems due to the higher temperatures.

Table 1. Cycle conditions used in $\mathrm{CO}_{2}$ split flow cycle

\begin{tabular}{|l|l|}
\hline Condition & Value \\
\hline Reactor Power & $600 \mathrm{MW}$ \\
Reactor Outlet Temp & $900 \mathrm{C}$ \\
IHX outlet heat flow & $600 \mathrm{MW}$ \\
Turbine Polytropic Efficiency & $92 \%$ \\
Compressor Polytropic Efficiency & $90 \%$ \\
IHX Effectiveness & $90 \%$ \\
Recuperator Effectiveness & $<95 \%$ \\
IHX Secondary Side Pressure Drop & $140 \mathrm{kPa}$ \\
High Temp. Recuperator Hot Side Pressure & \\
Drop & $50 \mathrm{kPa}$ \\
Low Temp. Recuperator Hot Side Pressure & \\
Drop & $50 \mathrm{kPa}$ \\
Precooler Pressure Drop & $50 \mathrm{kPa}$ \\
Compressor Inlet Temp & $31 \mathrm{C}$ \\
System Pressure & $20 \mathrm{MPa}$ \\
System Pressure Ratio & 2.6 \\
\hline
\end{tabular}

\section{- Implication of bottoming cycles}

A steam bottoming cycle can be used to further improve the efficiency of a cycle. The base design studied here was the Framatome cycle [Copsey, 2004]. The cycle efficiency of the combined cycle produces $49.56 \%$ due to the reduced pumping work for water in the Rankine cycle.

\section{- Implication of interstage heating and cooling to system layout}

Comparing the results of additional intercoolers as seen in Table 2, after the first intercooling stage is added, additional stages result in much smaller efficiency increases,. This decreasing efficiency gain is due to the additional pressure drop incurred by adding intercoolers. Eventually the efficiency increase from adding an intercooler will be off set by the additional cost of the intercooler. At that point the addition of another intercooler is not feasible. 
Table 2. Comparison of cycle implication due to various cycle layouts and intermediate cooling

\begin{tabular}{|c|c|c|}
\hline Cycle layout & Cycle Efficiency & $\begin{array}{c}\text { Differential } \\
\text { Efficiency Gain }\end{array}$ \\
\hline He Indirect no IC & $45.19 \%$ & N/A \\
\hline He Indirect 1 IC & $48.25 \%$ & $3.06 \%$ \\
\hline He Indirect 2 IC & $48.92 \%$ & $0.67 \%$ \\
\hline He Indirect 3 IC & $49.07 \%$ & $0.15 \%$ \\
\hline $\begin{array}{c}\mathrm{N}_{2} / \mathrm{He} \text { Indirect no } \\
\text { IC }\end{array}$ & $45.29 \%$ & $\mathrm{~N} / \mathrm{A}$ \\
\hline $\begin{array}{c}\mathrm{N}_{2} / \mathrm{He} \text { Indirect 1 } \\
\text { IC }\end{array}$ & $49.39 \%$ & $4.10 \%$ \\
\hline $\begin{array}{c}\mathrm{N}_{2} / \mathrm{He} \text { Indirect 2 } \\
\text { IC }\end{array}$ & $50.19 \%$ & $0.80 \%$ \\
\hline $\begin{array}{c}\mathrm{N}_{2} / \mathrm{He} \text { Indirect 3 } \\
\text { IC }\end{array}$ & 50.47 & 0.28 \\
\hline $\begin{array}{c}\text { CO } \\
2\end{array}$ Split Flow \\
\hline $\begin{array}{c}\mathrm{N}_{2} / \text { He Indirect } \\
\text { with a Combined } \\
\text { Cycle }\end{array}$ & 52.09 & N/A \\
\hline
\end{tabular}

Observations from this section include:

- Intercooler increases the cycle efficiency due to lowering the inlet temperature to the compressor. A single intercooler improves the cycle efficiency by approximately $3 \%$. Once the first intercooler is used, the second and third intercooler provide much smaller efficiency increases.

- $\quad$ The reheat option was not investigated in this chapter. However, the reheat option needs to be fully investigated for liquid coolants such as molten salts, where the ability to deliver heat with low pumping power allows low-pressure-loss heaters to be used and located close to the turbomachinery.

Reference:

Copsey, B. et al., The Framatome ANP Indirect-Cycle Very High Temperature Reactor, Proceedings of ICAPP'04, Pittsburgh, PA, June 13-17, 2004.

V. Dostal, M.J. Driscoll, P. Hejzlar, A Supercritical Carbon Dioxide Cycle for Next Generation Nuclear Reactors, March 10, 2004, MIT-ANP-TR-100

P. F. Peterson, Multiple-Reheat Brayton Cycles for Nuclear Power Conversion with Molten Salt, Nuclear Technology, vol. 144, December 2003. 
C. Wang, Design, Analysis and Optimization of the Power Conversion System for the Modular Pebble Bed Reactor System, MIT Ph.D. Thesis, August 31, 2003.

\section{Plans for Next}

We plan to explore the Brayton cycle improvement using various power conversion configuration. The baseline cases will be established with helium and eventually with high pressure $\mathrm{CO}_{2}$ system for comparison.

There are no concerns and no issues.

\section{Task 3. Material Compatibility}

During initial planning for the materials testing task of this NERI proposal two years ago alloy MA 754 was chosen for study due to preliminary reports of excellent creep properties at very high temperatures. Although preliminary data on the high temperature mechanical properties of these two alloys have been reported previously a more extensive investigation into their high temperature behavior was necessary before they could be considered from a structural viewpoint. However, the corrosion potential of this alloy in supercritical $\mathrm{CO}_{2}$ was completely unknown. Therefore, the companion alloy, MA 758 , was included in the workscope since its higher chromium content offered the potential of improved corrosion resistance should MA 754 exhibit unacceptable corrosion behavior. As a result, two areas of research were proposed - one examining the corrosion behavior of these alloys in supercritical $\mathrm{CO}_{2}$ and one examining the high temperature mechanical properties of these two alloys.

During the previous two years research showed that MA 754 did possess exceptional high temperature properties compared to other commercial high temperature alloys. Even though the mechanical properties varied significantly with direction in the sample relative to the extrusion direction, the long-term creep properties of MA 754 exceeded those of commercial alloys, see Fig. 1. 
Research on the corrosion behavior of MA 754 in supercritical $\mathrm{CO}_{2}$ also shows very little

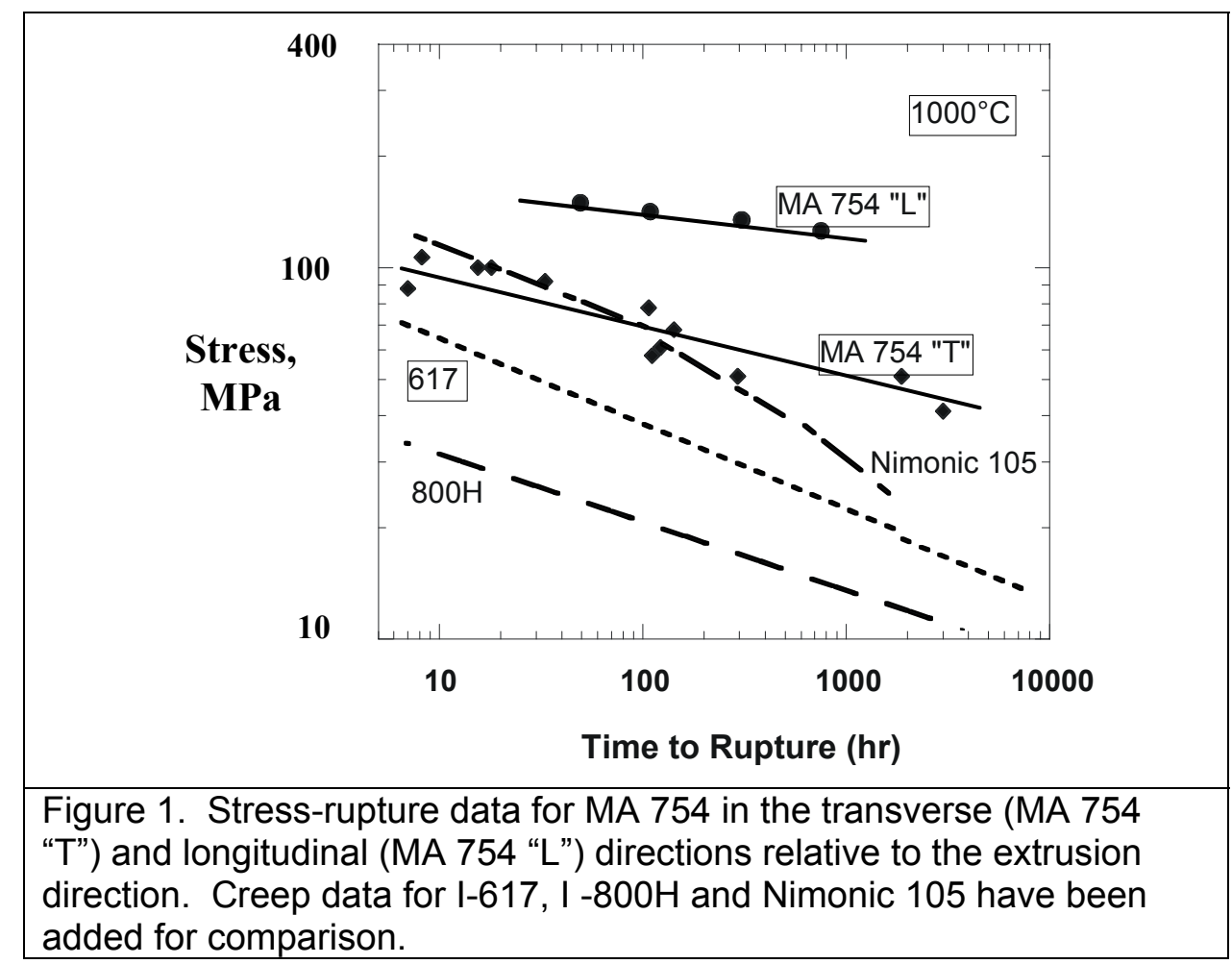

corrosion at $1000^{\circ} \mathrm{C}$ for tests up to 335 hours. At short exposure times ( $<100$ hours) to flowing supercritical $\mathrm{CO}_{2}$ the rate of corrosion is high but as the oxide layer forms and grows it acts to protect the material from further corrosion. This is illustrated in Figure 2 where the corrosion rate has been calculated as a function of exposure. The timeaveraged corrosion rate decreases as the exposure time increases.

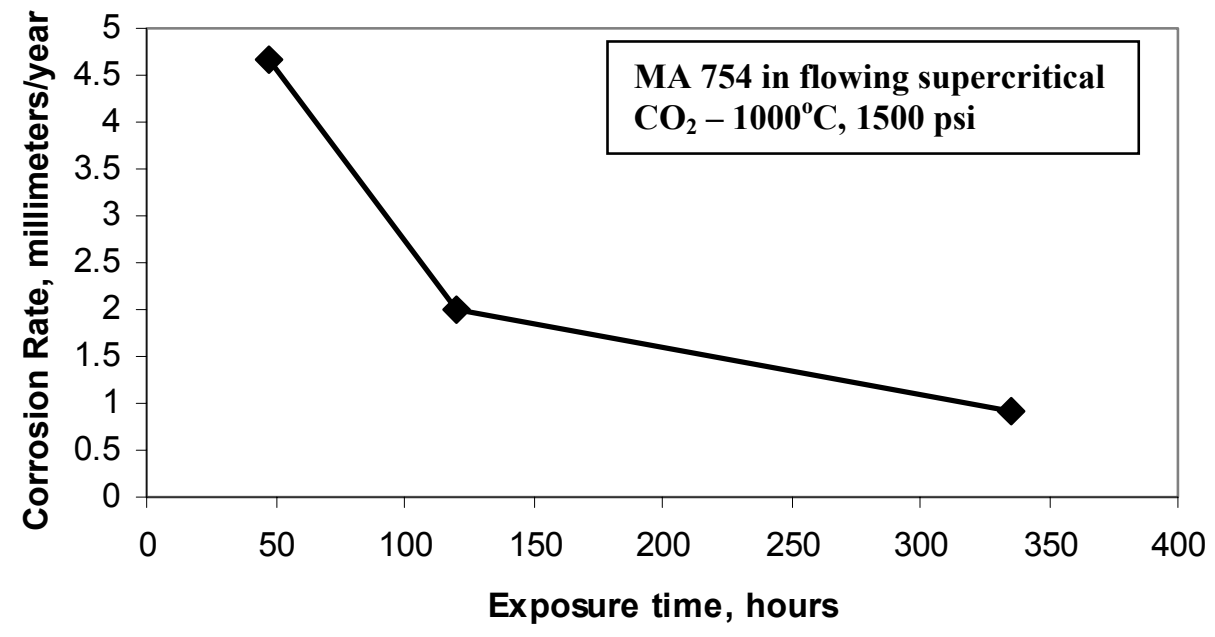

Figure 2. Plot of the time-averaged corrosion rate showing that once the corrosion layer forms further corrosion is slowed. 
From these results it would appear that MA 754 is a suitable material for application in a supercritical $\mathrm{CO}_{2}$ Brayton cycle, with more than adequate high temperature mechanical properties and corrosion resistance. As mentioned, the only difference between MA 754 and MA 758 is the chromium content (20 wt\% versus $30 \mathrm{wt} \%$ ). Both alloys contain the same amount of oxide particles that control the high temperature strength and creep resistance. Therefore the high temperature properties of MA 758 are expected to be very similar to those exhibited by MA 754. Variation of the chrome content is not expected to affect the mechanical properties significantly. Indeed, the high temperature tensile properties reported by the vendor for the two alloys are almost identical, lending credibility to the assumption that the creep properties of the two alloys should also be very similar. The higher chromium content of MA 758 is expected to exhibit improved corrosion resistance compared to MA 754 but corrosion resistance already has been shown to be a non-issue for MA 754. Therefore, it does not seem a valuable endeavor to study the high temperature creep and corrosion behavior of MA 758 for application to the supercritical Brayton cycle, since MA 754 has already been shown to be suitable for this application. The funds for research on MA 758 would be better spent elsewhere.

\section{Proposed Change to Task 3 Materials Testing}

Although MA 754 exhibits superior creep resistance coupled with excellent corrosion resistance it also suffers from limited ductility at elevated temperatures. A material that would fail more gracefully at elevated temperature would be more desirable even if some of the high temperature strength and creep resistance had to be sacrificed. One such alloy attracting considerable attention for use in the NGNP for high temperature applications is I-617. The high temperature properties of I-617 have been sufficiently characterized for it to be included in the ASME Boiler code Section III for use at temperatures up to $982^{\circ} \mathrm{C}$. Also the cost of I-617 is approximately half of that for MA 754.

The corrosion behavior of I-617 in supercritical $\mathrm{CO}_{2}$ is unknown. This alloy is also a nickel-based alloy containing chromium levels similar to MA 754, see Table 1 . However, I-617 contains substantial additions of both cobalt and molybdenum as compared to MA 754. So, although at first glance one would expect I-617 to exhibit corrosion behavior similar to MA 754, these additions of cobalt and molybdenum may complicate the corrosion response of I-617 in supercritical $\mathrm{CO}_{2}$. As a result the corrosion behavior of I617 in supercritical $\mathrm{CO}_{2}$ must be evaluated before the suitability of this alloy for the supercritical $\mathrm{CO}_{2}$ Brayton cycle can be determined.

\begin{tabular}{|c|c|c|c|c|c|c|}
\hline \multicolumn{6}{|c|}{ Table 1. Nominal Composition of Two High Temperature Nickel-based Alloys } \\
\hline Composition, wt\% & $\mathrm{Cr}$ & $\mathrm{Fe}$ & $\mathrm{Al}$ & $\mathrm{Co}$ & Mo & $\mathrm{Ti}$ \\
\hline MA 754 & 20 & 1 & 0.3 & - & - & 0.5 \\
\hline I -617 & 22 & - & 1 & $\mathbf{1 2 . 5}$ & $\mathbf{9}$ & - \\
\hline
\end{tabular}

Therefore, it is proposed that the efforts on Task 3 - Materials Testing be directed toward evaluating the corrosion behavior of this alloy in supercritical $\mathrm{CO}_{2}$ under conditions similar to those expected in the supercritical $\mathrm{CO}_{2}$ Brayton cycle. As mentioned, the high temperature mechanical properties have been evaluated elsewhere already and research in this project would be limited to evaluating the corrosion behavior. Over the past two years we have found that corrosion testing required more funding than originally anticipated. By limiting work to the evaluation of the corrosion 
behavior, more in depth information on the corrosion rate at long exposure times, composition of the corrosion products, mechanism of corrosion layer formation and corrosion layer stability can be determined. The revised workscope is given below:

Task 3-4 - Corrosion behavior of I-617 in supercritical $\mathrm{CO}_{2}$

Task 3-4-1 - Corrosion rate determination - Alloy l-617 will be exposed to supercritical $\mathrm{CO}_{2}$ at pressures ranging from $1000-1500$ psi and temperature ranging from $800-1000^{\circ} \mathrm{C}$. The corrosion rate will be determined from changes in sample weight and/or changes in base metal/corrosion layer thickness as a function of time.

Task 3-4-2 - Composition of Corrosion products - Corroded samples will be sectioned, mounted in epoxy and polished. The composition of the corrosion layer will be determined by means available on the SEM (either EDS or WDS x-ray spectrometry). If enough corrosion products can be collected $\mathrm{x}$-ray diffraction will be used to identify phases present in the corrosion product. The evolution of the corrosion layer will be tracked as a function of exposure time.

The funding would be split equally between the two tasks. The deliverable will be a report/publication on the corrosion behavior of I-617 in supercritical $\mathrm{CO}_{2}$. These changes have been incorporated into the Project Milestone section below.

\section{Task 3-1 Task Status and Significant Results}

The experimental work for this task was completed at the end of FY04. During the first quarter of FY05 the results of creep testing of fine grained MA 754 were summarized in a manuscript that was submitted for publication. This completed Task 3-1, Characterization of Creep Deformation of MA 754, which characterized the mechanical properties, at ambient and elevated temperatures, and the microstructures of both coarse-grained and fine-grained MA 754.

\section{Task 3-1-3, Mechanical and Creep Properties of Fine-grained MA 754}

The creep testing results of fine-grained MA 754 were incorporated into a manuscript and submitted to Metallurgical Transactions, A, for peer-review. The abstract of the paper is reproduced below:

Elevated Temperature Strength of Fine-Grained INCONEL Alloy MA754

T.C. Totemeier ${ }^{*}$, T.M. Lillo, and J.A. Simpson

Idaho National Engineering and Environmental Laboratory

P.O. Box 1625, MS 2218, Idaho Falls, ID 83415

\section{ABSTRACT}

\footnotetext{
*Corresponding author. Email: totetc@inel.gov
} 
Elevated temperature tensile and creep-rupture tests were performed on INCONEL alloy MA754 in an as-rolled, fine-grained condition. Tensile tests were performed at $25,800,900$, and $1000^{\circ} \mathrm{C}$; creep-rupture tests were performed at 800,900 , and $1000^{\circ} \mathrm{C}$. The elevated temperature strength in the fine-grained condition was approximately $25 \%$ of the standard, coarse-grained annealed condition. While good ductility was observed in tensile tests at a nominal strain rate of $1 \times 10^{-3}$ $\sec ^{-1}$, ductility in creep-rupture tests was very low, with failure elongations less than $5 \%$ and no reduction in area. Creep deformation appeared to occur solely by cavity formation and growth.

This subtask is now complete.

Task 3-2-2 Corrosion Testing of MA 754 in Supercritical $\mathrm{CO}_{2}$

The long term test sample of coarse-grained MA 754 required modification of the end connections and was not run during the first quarter of FY05. Modifications to the sample have been made and it is now ready for testing. A 500 hour test is planned for this final coarse-grained MA 754 sample. Fine-grained MA 754 samples are also ready for testing and are expected to be completed by the end of the second quarter of FY05.

Also we have recently acquired the use of another supercritical $\mathrm{CO}_{2}$ testing system. It had previously been used to study the corrosion behavior of various alloys in supercritical $\mathrm{CO}_{2}$ at temperatures in the $500-700^{\circ} \mathrm{C}$ range. Relatively minor modifications are being made to allow higher temperature testing

This test loop will allow multiple corrosion samples to be tested simultaneously under similar environmental conditions. A schematic of the system is shown in Figure 3. The test loop consists of high purity $\mathrm{CO}_{2}$ cylinders, high-pressure $\mathrm{CO}_{2}$ pumps, filters, a flow meter, a pre-heated test section, and high-pressure fittings and valves. This loop is very similar to the current test loop in that it is a once-through apparatus using $\mathrm{CO}_{2}$ gas with a purity of $99.99 \%$ but it will allow multiple samples to be tested simultaneously. The samples are contained within pressurized tubes inside a resistance heated horizontal tube furnace capable of temperatures in excess of $1100^{\circ} \mathrm{C}$, Figure 4 . The pressure tubes within the tube furnace are thick-walled 304 stainless steel tubes capable of withstanding an internal pressure of $11 \mathrm{MPa}$ for 10,000 hours at $1000 \mathrm{C}$. 


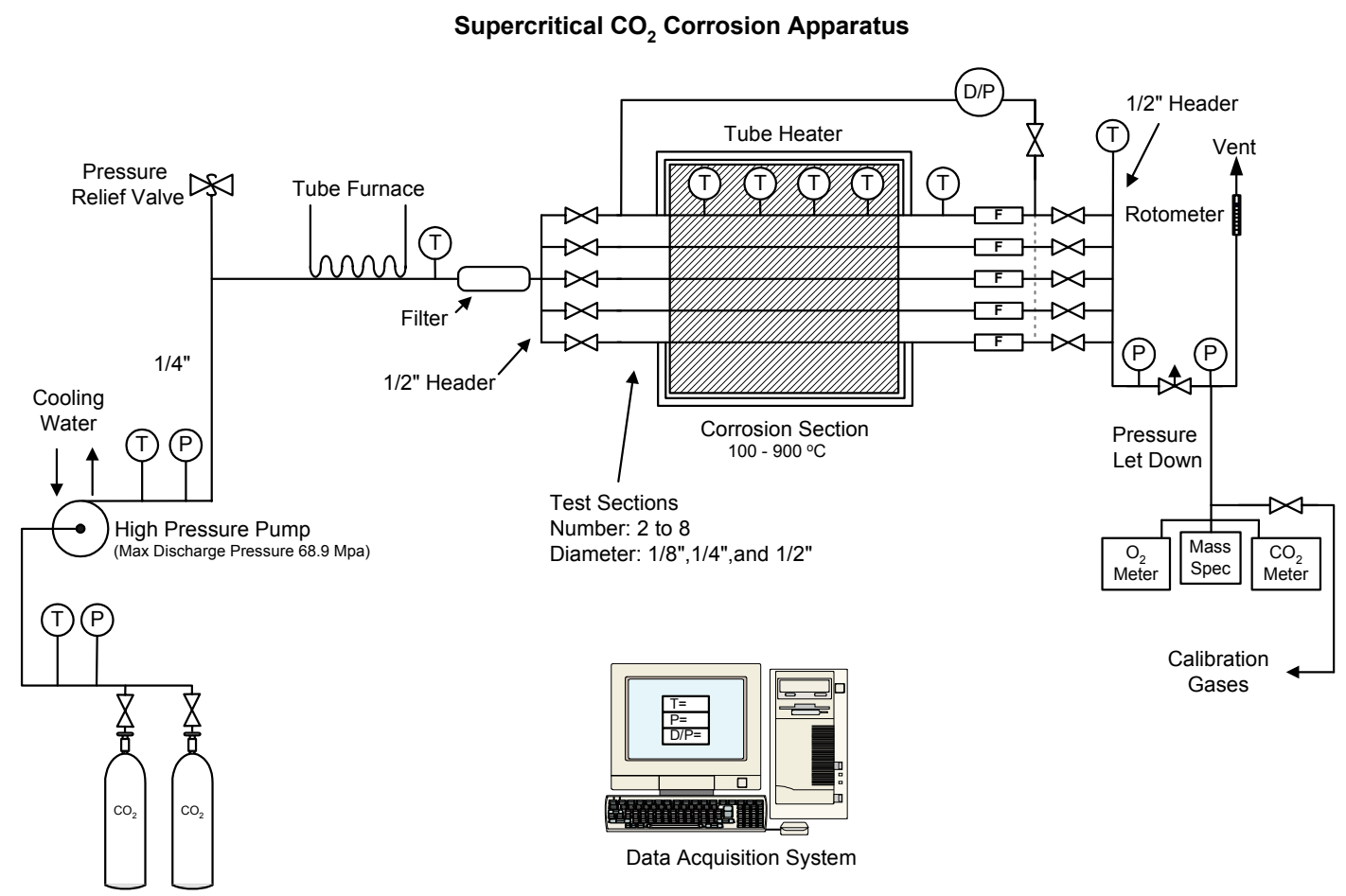

Figure 3. Schematic of the supercritical $\mathrm{CO}_{2}$ corrosion testing system capable of testing multiple samples simultaneously.

The $\mathrm{CO}_{2}$ gas is fed into the test loop from compressed $\mathrm{CO}_{2}$ cylinders and then pumped to the experimental operating pressure by an ISCO D-series syringe pump Model 500D. The pump takes an input pressure of $5.7 \mathrm{MPa}$, and discharges up to $21 \mathrm{MPa}$ with a maximum mass flow rate of $170 \mathrm{ml} / \mathrm{min}$. The pumps are capable of control based on feedback from a pressure sensor or a flow meter. The microprocessor supplied by the vendor monitors either the flow meter or the loop static pressure and adjusts the pump speed as necessary. The pump speed, loop pressure, and volumetric flow are sent via RS232 cable to a computer for data acquisition.

Multiple stainless steel tubes can be placed within the large ceramic tube opening of the horizontal furnace. This can allow multiple samples, materials, and configurations to be tested within the experimental loop simultaneously. As a result, a much better statistical representation of the corrosion rate is achievable with this improved design. 


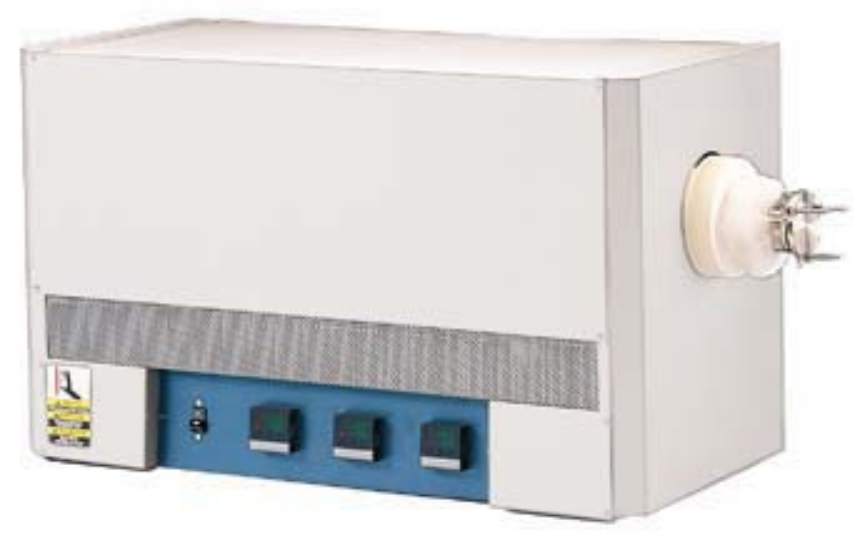

Figure 4. Horizontal tube furnace capable of $1200^{\circ} \mathrm{C}$ temperatures.

\section{Plans for Next}

- Complete corrosion testing of coarse-grained MA 754 and compose a manuscript for a peer-reviewed journal reporting the results. Task 3-2-2.

- Begin corrosion testing fine-grained MA 754. Task 3-2-3

- $\quad$ Begin corrosion testing of I-617. Task 3-3-1

\section{Project Milestones}

The project milestones are shown below:

\begin{tabular}{|l|l|l|}
\hline Milestone/Deliverable Description & $\begin{array}{l}\text { Planned } \\
\text { Completion }\end{array}$ & Actual Completion \\
\hline $1 . \quad \begin{array}{l}\text { Development of CO2 Brayton } \\
\text { Cycle }\end{array}$ & 30 June 2003 & Completed \\
\hline $1-1 \begin{array}{l}\text { Development of the efficiency } \\
\text { equation of turbine and } \\
\text { compressor for the real gas }\end{array}$ & 31 March 2003 & Completed \\
\hline $1-2 \begin{array}{l}\text { Check of supercritical CO2 } \\
\text { properties with equation of state }\end{array}$ & 31 March 2003 & Completed \\
\hline $1-3 \begin{array}{l}\text { Selection of the optimization } \\
\text { computer code }\end{array}$ & 31 March 2003 & Completed \\
\hline $1-4 \begin{array}{l}\text { Layout of CO2 thermal cycle and } \\
\text { initial calculations }\end{array}$ & 31 March 2003 & Completed \\
\hline
\end{tabular}




\begin{tabular}{|c|c|c|}
\hline 1-5 Perform baseline calculations & 30 June 2003 & Completed \\
\hline $\begin{array}{l}\text { 2. Improvement of Brayton cycle } \\
\text { efficiency }\end{array}$ & 30 September 2005 & $\begin{array}{l}\text { Starts in the } 4^{\text {th }} \text { quarter of } \\
\text { FY-03 }\end{array}$ \\
\hline $\begin{array}{l}\text { 2-1. Enhancement of each } \\
\text { component's efficiency }\end{array}$ & 31 March 2004 & $\begin{array}{l}\text { Starts in the } 4^{\text {th }} \text { quarter of } \\
\text { FY-03 }\end{array}$ \\
\hline 2-2. Optimization of PBR schematic & 30 September 2005 & $\begin{array}{l}\text { Starts in the } 2 \text { nd quarter } \\
\text { of } \mathrm{FY}-04\end{array}$ \\
\hline $\begin{array}{l}\text { 2-2-1 Develop PBR optimization } \\
\text { model }\end{array}$ & 30 September 2005 & $\begin{array}{l}\text { Starts in the } 2^{\text {nd }} \text { quarter of } \\
\text { FY-04 }\end{array}$ \\
\hline $\begin{array}{l}\text { 2-2-2 Efficiency and cost comparison } \\
\text { calculations }\end{array}$ & 30 September 2005 & $\begin{array}{l}\text { Starts in the } 2^{\text {nd }} \text { quarter of } \\
\text { FY-04 }\end{array}$ \\
\hline Material testing & 30 September 2005 & In progress \\
\hline $\begin{array}{l}\text { 3-1 Characterization of creep } \\
\text { deformation of MA } 754\end{array}$ & 30 September 2004 & Complete \\
\hline $\begin{array}{l}\text { 3-1-1 Characterization of initial } \\
\text { microstructure }\end{array}$ & 30 June 2003 & Completed \\
\hline $\begin{array}{l}\text { 3-1-2 High temperature mechanical } \\
\text { and creep properties of MA } 754\end{array}$ & 31 December 2003 & Completed \\
\hline $\begin{array}{l}\text { 3-1-3 Mechanical and creep } \\
\text { properties fine-grained MA } 754\end{array}$ & 31 August 2004 & Complete \\
\hline 3-2 Thermogravimetric analyses & 30 April 2005 & In progress \\
\hline $\begin{array}{l}\text { 3-2-1 Design and construction of } \\
\text { supercritical CO2 test loop }\end{array}$ & 30 June 2003 & Completed \\
\hline $\begin{array}{l}\text { 3-2-2 Corrosion testing of MA } 754 \text { in } \\
\text { supercritical CO2 }\end{array}$ & 30 April 2005 & In progress \\
\hline $\begin{array}{l}\text { 3-3 Corrosion behavior of I-617 in } \\
\text { supercritical } \mathrm{CO}_{2}\end{array}$ & 31 August 2005 & Starts $2^{\text {nd }}$ quarter of $\mathrm{FY} 05$ \\
\hline 3-3-1 - Corrosion rate determination & 31 August 2005 & \\
\hline $\begin{array}{l}\text { 3-3-2 - Composition of Corrosion } \\
\text { products }\end{array}$ & 31 August 2005 & \\
\hline $\begin{array}{l}\text { 3-4 Final report on corrosion behavior } \\
\text { of MA } 754 \text { and } \mathrm{I}-617 \text { in } \\
\text { supercritical } \mathrm{CO}_{2}\end{array}$ & 30 September 2005 & Starts $4^{\text {th }}$ quarter of FY05 \\
\hline
\end{tabular}




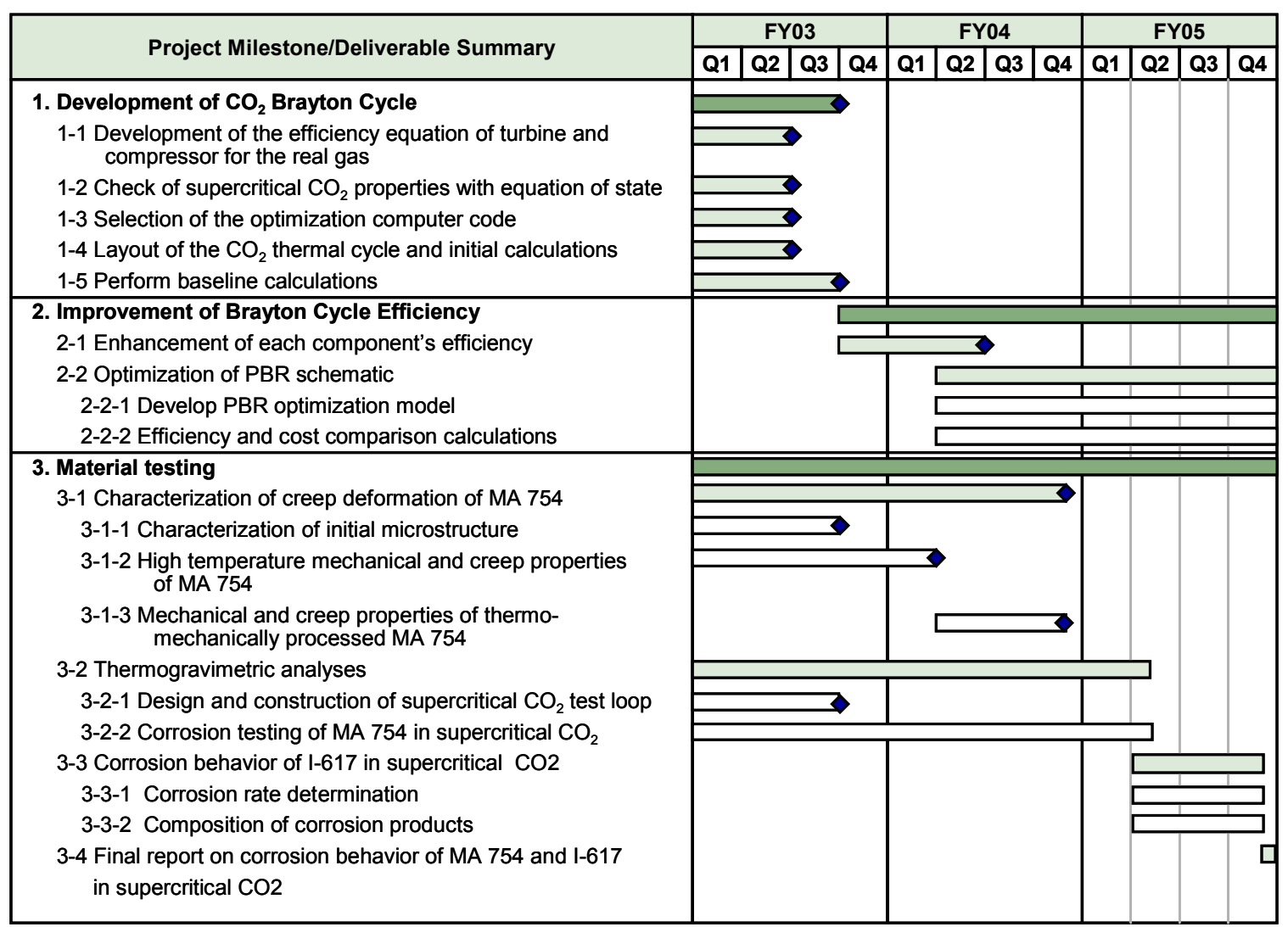

$\checkmark$ Completion

04-GA50018-02 